\title{
BEVIDSTHED I BEVAGELSE OM DEN JAPANSKE FORFATTER NATSUME SŌSEKIS SANSEBEVIDSTHED
}

\section{CONSCIOUSNESS AS MOVEMENT - ACCORDING TO NATSUME SŌSEKI | In}

his Theory of Literature from 1907, Japanese writer Natsume Sōseki (1867-1916) describes feelings as pivotal in literature worldwide. Fredric Jameson places Sōseki among the major modernists in the twentieth century. Like the western modernists, Sōseki was inspired by William James' concept stream of consciousness, developing his own idea about literature as an affective type of continuity of consciousness. This article investigates how this idea influences the representation of characters in his

last, unfinished feuilleton novel, Light and Dark from 1916. The article argues that a comparison with current day affect theory calls attention to how Sōseki not only portrays the bodily emotions, but also consciousness as embodied and embedded in particular social spaces. In this novel Sōseki depicts or sketches minor feelings or everyday affects as closely related to the experience of modernity. By exploiting its feuilleton form, Light and Dark shows how new modes of perception and movement produce affects that stick to bodies (rather than spring from them). The article thus suggests seeing Light and Dark as a critical and nuanced comment on modernity and its discourses on emotions.

KEYWORDS I Sōseki, modern Japanese literature, stream of consciousness, affect, embodiment, serialization, everyday aesthetics, representation.

I The Modernist Papers fra 2007 beskriver litteraturteoretikeren Fredric Jameson den japanske forfatter Natsume Sōseki (I867-I9I6) som en af de helt store modernister i det tyvende århundrede. Sōseki, der regnes for en af Japans største moderne forfattere, var - som flere modernister i øvrigt - inspireret af den amerikanske filosof og psykolog William James' begreb om stream of consciousness. I forlængelse af James udviklede Sōseki en ide om litteraturen som en særligt affektiv form for bevidsthedskontinuitet. ${ }^{\mathrm{I}}$ Denne artikel analyserer, hvordan det mere præcist kommer til udtryk i hans sidste føljetonroman Lys og mørke fra I9I6.

Sōseki er i dag bedst kendt som romanforfatter, men var også en af sin tids førende litteratur- og modernitetskritikere i Japan. Han skrev i en periode, hvor Japan efter mere end to hundrede års isolationspolitik blev moderniseret efter vestligt forbillede. Jameson ser i Japans intensive moderniseringsproces træk, der minder

I Sōseki bruger begge udtryk bevidsthedsstrøm og -kontinuitet (ishiki no nagare og ishiki no renzoku). 
om udviklingen i Vesten, men i en ny form. ${ }^{2}$ Det er denne artikels argument, at Sōsekis detaljerede bevidsthedsbeskrivelse og iscenesættelse af hverdagsaffekt må ses som nært knyttet til denne intensive modernitetserfaring. Lys og mørke skitserer helt ned i detaljen, hvordan ny videnskab og teknologi og dermed nye perceptions- og bevægelsesmåder påvirker bevidstheden og kroppen. Dermed beskrives nuanceret en form for modernitetsaffekt, der rejser andre kritiske spørgsmål end de rent psykologiske, om hvordan vi forstår følelser.

Følelser i litteraturen er ifølge Sōseki ikke nødvendigvis skønne eller sublime. Litteraturen kan gøre brug af alle mulige følelser. Som affektteoretikeren Sianne Ngai påpeger, excellerer den moderne litteratur ligefrem i grimme og hverdagsagtige følelser. Det er ikke singulære eller ophøjede følelser. Sådanne hverdagsaffekter er derimod ofte sammensatte og komplekse sammenkrydsninger af almindelige følelser. De opstår i bestemte sociale situationer og relationer og er dermed ikke afgrænselige til et psykologisk indre. Lys og mørkes særlige iscenesættelse af hverdagsaffekt mener jeg, kan forstås ud fra en sådan affektteoretisk tilgang. Med affektteoretikeren Brian Massumi kan man også sige, at romanen skitserer en affektiv intensitet, der virker på overfladen af kroppe. Lys og mørke udnytter, som artiklen vil vise, selve føljeton-formen til at illustrere, hvordan bevidstheden kontinuerligt påvirkes af de sociale og affektive rum. ${ }^{3}$ Sōseki kombinerer i romanen beskrivelsen af hverdagsdetaljer med sin ide om en affektiv form for bevidsthedsstrøm. Lys og mørke er i den forstand en roman, der vil beskrive kroppen og sindets samtidige rørelse $\mathrm{i}$ et samfund i forandring.

\section{Hverdagscestetik}

Allerede i sin Litteraturteori (Bungakuron) fra 1907 beskriver Natsume Sōseki følelserne som litteraturens omdrejningspunkt.4 I sin definition af følelser henviser han til den franske psykolog Théodule-Armand Ribot (I839-I9I6), der forbinder følelserne til kroppen. Ribot mente, at man fysiologisk kunne beskrive det affektive livs evolution fra de basale kropslige emotioner til de mere komplekse følelser. Sōseki følger de fysiologiske teorier så langt som til at forklare brugen af basale emotioner i litteraturen. Jo mere konkrete eller sanselige indtryk er, jo lettere (mere umiddelbart) vækker de følelser, mener han. Som i et køkken er det dog ikke ingredienserne alene, der afgør resultatet, skriver han endvidere. I litteraturen er retoriske og æstetiske konfigurationer i høj grad med til at skabe følelser og stemninger (Natsume, Theory 53-65). Sammen med digteren Masaoka Shiki udviklede Sōseki en moderne hverdagsæstetik, shaseibun, "skitse-stil”, der lagde vægt på det

2 " $[\mathrm{I}] \mathrm{t}$ is as though that great laboratory experiment which was the modernization of Japan allows us to see the features of our own development in slow motion, in a new kind of form" (Jameson 283).

3 Jf. Tygstrups "Affektive rum" i dette nummer af Kひ K, der understreger følelsesdiskursens historicitet.

4 "[E]motion constitutes the single test case for literature, the beginning and the end of the question" (Natsume, Theory 65; SZ I4: I05). I det følgende refererer jeg til den engelske oversættelse Theory of Literature fra 2009. På japansk anvender han ordet 情緒 (jyōsho eller jyōcho), der enten kan oversættes som folelse eller som stemning. 
konkret erfarede og gjorde op med tidligere tiders konventioner. 5 "At eksistere som middel for et forudbestemt mønster er at udføre en mekanisk funktion for en livløs skals skyld," skriver han i et essay fra I9Io om fordelene og ulemperne ved -ismer. ${ }^{6}$ Naturalistisk, romantisk og realistisk litteratur fra Vesten blev oversat sideløbende i Japan, hvilket kan være en grund til, at Sōseki kan se litterære -ismer som stilelementer, der kan redefineres og blandes på ny. Eftersom han var uddannet i engelsk litteratur, læste han desuden alt fra Laurence Sterne til Jane Austen foruden andre vestlige såvel som kinesiske og japanske klassikere. Denne alsidige indflydelse skinner også igennem i hans romaner.

\section{Bevidsthedskontinuitet}

Omtrent samtidig med vestlige modernister som Virginia Woolf og James Joyce var Sōseki særligt inspireret af William James' ide om stream of consciousness. Narratologisk set kommer indflydelsen dog til udtryk på noget anden vis i Sōsekis værker end hos de vestlige modernister (der desuden snarere overtog begrebet end ideen som sådan). 7 I Principles of Psychology fra I89o overvejer James først at anvende udtrykket train of thought til at beskrive det flux eller den forandring, bevidstheden er i, men foreslår senere stream of consciousness, da det indikerer kontinuitet og inkluderer følelserne (James I86). For Sōseki, som for James, er bevidsthedsstrømmen således uløseligt knyttet til følelserne (og kroppen). Sōseki beskriver i sin litteraturteori øjeblikket som en opmærksomhedsbølge. I psykologien er det ofte eksemplificeret ved læsningen af en tekst (eller ved at lytte til et stykke musik). ${ }^{8}$ Et indtryk eller en ide vil i litteraturen være akkompagneret af en følelse, der har en vis udstrækning, foreslår Sōseki. Til grafisk at illustrere dette anvender han en model, der viser en stående halvcirkel, hvis toppunkt svarer til et øjeblik. ${ }^{9}$ Det forudgående øjeblik er præsent i periferien, og samtidig anticiperes det næste. Bevidsthedsstrømmen må

5 Shiki er særligt kendt for at have moderniseret haiku-genren til den form, som den bliver forstået i Vesten i dag. Før Shiki hed 5-7-5-formen bokku og indgik som indledningsvers i kollektive renga digtcyklus-traditioner, og senere i den uortodokse haikai-no-renga (sidstnævnte var den form, den berømte digter Bashō i I6oo-tallet dyrkede).

6 " $[\mathrm{I}] \mathrm{f}$ our mental lives were to fall under the sway of some -ism, that predetermined pattern would immediately cause us to feel constrained in our existence. To exist as the vehicle for some predetermined pattern is to perform a mechanical function for the sake of a lifeless shell." ("The Merits and Flaws of -isms", Natsume, Theory 240).

7 Forskellene består dels i, at det grammatiske subjekt er implicit på japansk, dels i, at Sōseki var med til at perfektionere en ny form for mere talesprogslignende prosastil. Nakamura Shinichiro sammenlignede allerede i 195I Sōsekis skrivestil med stream-of-consciousness, men forslaget kritiseredes, fordi hans teknik ikke ækvivalerer de vestlige modernisters stream-of-consciousness-teknik. De vestlige modernisters teknik er dog heller ikke ligefrem entydig. Se fx Moretti I74. Mit forslag er at tale om forskellige litterære udlægninger af begrebet verdenslitteraturhistorisk set.

8 "[W] $[$ hen one isolates for observation a moment of consciousness from the continuity of a particular conscious state, one can see that the preceding psychological state begins to attenuate, while the portion to follow, by contrast, is gradually raised in distinctness through anticipation" (Natsume, Theory 55).

9 Modellen har han fra Lloyd Morgans Introduction to Comparative Psychology fra I896, der ligeledes bygger på James. 
ifølge Sōseki forstås som en serie af sådanne bevidsthedsmæssige bølgeformer. Øjeblikket er altså ikke et punkt på en linje, men har en spatio-temporal horisont. Io James beskriver også nuet som et skib, der både peger mod fortiden og fremtiden. Det er denne tidslige ide om bevidsthedskontinuitet, Sōseki videreudvikler i sine romaner. Litteraturen er ifølge Sōseki orienteret mod følelserne, men også mod selve bevidsthedskontinuiteten. (Natsume, Theory I59-I80)

\section{Affekt på overfladen}

Sōseki begyndte i 1905 selv at skrive føljetonromaner, først til det litterære tidsskrift Hototogisu ("en lille gøg"), senere som fast skribent og litteraturredaktør for Asahi-avisen. Hans sidste og ufuldendte roman Lys og mørke (明暗, Meian) blev

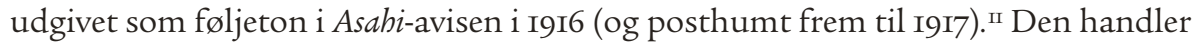
som mange af hans andre romaner om konflikter mellem familiære forpligtelser, ægteskab, venskab, kærlighed og individualisme i det moderne Japan. Lys og mørke fokuserer således på protagonisten Tsudas komplicerede forhold til sin unge hustru, O-Nobu, og en ungdomsforelskelse, Kiyoko.

Romanen begynder in medias res med, at protagonisten Tsuda befinder sig i en lægekonsultation: "Da lægen havde undersøgt fistlen, hjalp han Tsuda ned af operationsbordet.” ${ }^{\text {I2 }}$ Meget mere in medias res bliver det næppe. Første sætning skaber en forventning om en forklaring på undersøgelsen. Dermed etableres en form for øjeblikkets suspense (minimalsuspense kunne man kalde det). Protagonisten Tsuda hænger ligesom i luften et kort øjeblik - spændt ud mellem håb og ængstelse. Lægen forklarer i en venlig objektiv tone, at fistlen gik dybere end først antaget, men at en operation muligvis kan kurere sygdommen og få de to sider til at hele. Sōseki ekspliciterer, at Tsuda registrerer en lettere beklagelse i lægens kropsholdning, og det er et gennemgående træk i romanen, at følelserne beskrives yderst detaljeret i forhold til kroppen.

Indledningsafsnittet er emblematisk af flere grunde. På vej ind til lægen fik Tsuda nemlig lov til at kigge gennem et mikroskop:

”Tæt ved ham, på bordet ved det sydlige vindue, var der placeret et mikroskop. Eftersom han var kommet på venskabelig fod med lægen, havde han, da han tidligere var kommet ind, ud af forundring fået lov at kigge igennem det. Under linsen, der forstørrede tingene under det otte hundrede og halvtreds gange, havde han tydeligt

Io Bergson, som Sōseki også læste, formulerer omtrent samtidig med James en lignende ide om øjeblikkets tidslige udstrækning eller varen (durée).

II Romanen er oversat til flere sprog, dog ikke til dansk. Jeg henviser her til Viglielmos engelske oversættelse Light and Darkness fra 1972 og Iwanami-forlagets Sōseki zenshu-udgivelse (SZ). John Nathan arbejder for øjeblikket på en nyoversættelse med titlen Light and Dark.

I2 En fistel er en abnormal ofte rørformet forbindelse mellem indre eller ydre organer pga. en sygelig proces i dybden. På japansk nævnes fistlen først i anden sætning: ”Da lægen havde undersøgt [fistlen], lod han ['wo oroshita'] Tsuda komme ned fra operationsbordet. 'Fistlen ...”' (SZ II: 3) 
set farvede botryoidale/drueklaseformede baciller, som var de livagtigt skitseret i detaljen.” (Natsume, Light 2; SZ II: 4)

De små bakterier forekommer virtuelle i mikroskopet, og disse mikroskopiske forandringer bliver et billede på de ikke-bevidste forandringer, Tsuda får at vide foregår i hans egen krop. Den fysiologiske psykolog Ribot, hvis værk om følelsernes psykologi Sōseki refererer til i sin litteraturteori, beskriver dette ikkebevidste niveau: "neden under det bevidste følelsesliv eksisterer der en simpel og ukendt region, en vital og organisk sensibilitet, der er en embryonisk form for bevidst sensibilitet, hvoraf det understøttes. Vi bevæger os nu fra mørke til lys, fra det vitale til det psykiske." '13 Ribot ser de organiske processer, der er i mørke, som forstadier til de bevidste følelser. Sōsekis romantitel Lys og mørke er på japansk et ord, der er sammensat af to ideogrammer: 明 lys og 暗 mørke. Det indikerer dels kontrast, en lys/skygge-æstetik - som er understreget i den franske oversættelse til Clair-obscur - men peger således også på forholdet mellem det bevidste og ikke-bevidste. ${ }^{\mathrm{I}}$ Det i bevidstheden, der er i lys, og det, der er i mørke. I romanen bliver dette ikke-bevidste et billede på selve forandringen i kroppen og sindet, de små ofte ikke-bevidste overgange fra et øjeblik til et andet, fra en tilstand til en anden. Affektteoretikeren Brian Massumi beskriver i sit udkast til en affektteori fra 2002 netop sådanne mikro-perceptioner som overgange, der er svært registrerbare eller ikke-bevidste. Denne ide er i øvrigt med til at definere affektteorien mere generelt, når fx Seigworth og Gregg i "An Inventory of Shimmers" ser affekt som "molekulære begivenheder, der ikke lader sig registrere med det blotte øje" (Seigworth og Gregg 2), eller når Ngai beskriver ofte svært registrérbare glimt af affekt. (Ngai, Our I8). ${ }^{5}$ Det ikke-bevidste indbefatter i Massumis affektoptik både noget aktuelt og virtuelt. Det skal vi tilbage til William James for at se, hvad han mere præcist mener med.

Ifølge William James' senere radikale empirisme er relationer nemlig noget følt. Selv små overgange i sproget, konjunktioner som men eller og, er fx følte. ${ }^{16}$ Det er de helt kropsligt vel at mærke, selvom vi ikke almindeligvis er bevidste herom. Massumi videreudvikler James' ide om de følte overgange ved at koble den med Spinozas ide om transition. Massumi foreslår at se de ikke-bevidste mikroperceptioner som en form for virtualitet. Som for Spinoza er kroppen et med dens transition, relationen mellem bevægelse og stasis. Dette virtuelle betegner han derfor med reference til James som overgangenes følte virkelighed (the felt reality of relation). Virtualiteten

I3 Sōseki læste den engelske oversættelse fra I897: "We now pass from darkness to light, from the vital to the psychic." (Ribot 7-8) Udgaven, der citeres fra her, er fra I9II.

I4 Det ikke-bevidste er ikke at forveksle med det freudianske ubevidste - selvom det ifølge Massumi heller ikke er fuldstændig urelateret. Under alle omstændigheder får selve forestillingen om dette ikke-bevidste liv en fremmedgørende effekt i romanen.

I5 " $[\mathrm{T}]$ he feeling of transition by nature stretches between phases of a continuing movement [...] A complication for radical empiricism is that the feeling of the relation may very well not be 'large' enough to register consciously. It may be what Leibniz termed a 'small perception', or microperception (chapter 8)." (Massumi I6).

I6 Se Mark Johnsons artikel "Feeling James' 'But”' for en anden udlægning af de følte konjunktioner hos James. 
er led i det virkeliges transition. Det aktuelle og virtuelle er med andre ord lige virkelige ifølge Massumi. ${ }^{17}$

Ifølge Massumi har man i (vestlig) filosofi længe fokuseret på krop-forandringsrelationen, men netop glemt overgangene, det virtuelle, der sker indimellem: nemlig følelse/bevagelse. ${ }^{18}$ Sōseki tog imidlertid allerede i 1907 udgangspunkt i følelsernes bevagelse i sin beskrivelse af litteraturen som bevidsthedskontinuitet.19 Selv almindelige mennesker er udsat for suggestion i deres liv, og denne suggestion fører til forandring, som han skriver i sin litteraturteori. ${ }^{20}$ Det kan omformuleres til en affektteoretisk pointe: Krop og sind bevæges samtidig under påvirkning (af indtryk og ideer) udefra. Massumis ide er netop en ikke-dualistisk pluralisme, at koble James' radikale ide om følte relationer med Spinozas monistiske ide om affekt som noget, der enten kan øge eller formindske handlekraften. ${ }^{21}$ Hvordan denne ide om affektivitet nærmere bestemt smitter af på selve fremstillingen af affekt i Lys og mørke bliver tydeligt allerede i romanens andet kapitel. Oplevelsen hos lægen vender nemlig tilbage til Tsuda, da han kort tid efter konsultationen er på vej hjem i en overfyldt sporvogn. Mens han klamrer sig til en læderstrop for at holde balancen, følger vi hans citerede indre monolog, hvor inspirationen fra James' stream of consciousness er særlig tydelig:

"'Det er ikke udelukket at denne krop hvert øjeblik kan undergå en forandring. Tværtimod, er der måske netop nu ved at finde en forandring sted inden i denne krop.' Han kunne ikke stoppe tankerne i sit hoved, nu hvor de var nået så langt. I samme øjeblik blev han skubbet fremefter, som om en kraft bagfra ville vælte ham. Pludselig lød et udbrud i hans sind/hjerte [kokoro]: 'Det er det samme med følelserne. Med følelserne er det virkelig det samme. Vi ved ikke, hvornår eller hvordan de forandrer sig. Desuden har jeg jo selv set, hvordan de forandrer sig. Det er skræmmende.' [...] Ligesom den sporvogn, han kørte i, fortsatte hans tanker blot fremad på deres egne skinner.” (Natsume, Light 3; SZ II:7)

I7 "The issue, after sensation, perception, and memory, is affect ... The Spinozist problematic of affect offers a way of weaving together concepts of movement, tendency, and intensity". (Massumi I6)

I8 "Paraphrasing Deleuze again, the problem with the dominant models in cultural and literary theory is not that they are too abstract to grasp the concreteness of the real. The problem is that they are not abstract enough to grasp the real incorporeality of the concrete" (Massumi 5). Deleuze var yderst optaget af den radikale empirisme, James formulerer i sine senere værker.

I9 Den lidt senere japanske tænker Nishida så i James' ide om "pure experience" en forbindelse til zen-buddhismens ikke-dualisme. Hvor Nishida udvikler ideen om bevidsthedsstrømmen i en religiøs normativ retning, er det langtfra tilfældet hos Sōseki, der tværtimod insisterer på pluraliteten af følelser i litteraturen.

20 I sin litteraturteori drager han ligefrem en parallel mellem hypnosen og den samfundsmæssige påvirkning af individet: "One physician tells the story of a woman on whom he was about to operate who lost consciousness just as he was placing the mask on her face and before he had even administered the anesthesia" (Natsume, Theory 136). "It is suggestion that makes change possible." (Natsume, Theory I47) and "even ordinary people are constantly subject to suggestion in their everyday lives and that this suggestion brings about change in their consciousness" (Natsume, Theory 137).

2I Jf. James' (og Langes) kendte omvending af den almindelige ide om kausalforholdet: "Vi ser en bjørn, bliver bange og løber" til "Vi ser en bjørn, løber og bliver bange". Det vil sige, den rent kropslige reaktion går forud for den bevidste følelse. 
Der finder en overblænding sted, hvor krop og tanker flyder sammen. Sporvognens fysiske bevægelse bliver metafor for Tsudas imagination, der kører af sted på sine egne spor. Det virtuelle spiller med andre ord (Massumis) ind i det aktuelle og vice versa, som medrejsende i samme virkelighed. Sōseki lader Tsuda associere videre og skaber dermed en parallel mellem det fysiske og det følelsesmæssige. Den fysiske bevægelse sidestilles med de ikke-bevidste forandringer i kroppen, som bliver noget både nærværende og fremmed, dvs. nærmest unbeimlich. Det er skræmmende (恐ろ しい事だ), udbryder Tsuda for sig selv. Og vi ved ikke rigtig, om det er de kropslige, mikrobiologiske forandringer, han har set gennem mikroskopet, eller følelsernes forandring, der er mest skræmmende. I toget har alle de forudgående indtryk hos lægen afsat sig som en umiddelbar affekt på hans krop. ${ }^{22}$

Det skal her blot kort bemærkes, at Tsudas indre monolog på japansk er markeret som skarpt adskilt fra fortællerstemmen. Romanen ekspliciterer, at dramaet foregår i hans (kare no) sind/hjerte. ${ }^{23}$ Det er diametralt modsat af vestlige modernisters udvikling af en discours indirect libre, der snarere slører denne grænse. ${ }^{24}$ Sōseki veksler mellem at gengive Tsudas tanker og følelser som citeret indre monolog og fortællerstemmens beskrivelse af hans samtidige fysiske og psykiske rørelse. Tsudas tankestrøm influeres hele tiden af indtryk og ideer udefra. Tsuda tænker videre og kommer i tanke om den franske matematiker og filosof Poincarés kaosteori:

"[Tsuda] kom i tanke om, hvad en ven to eller tre dage tidligere havde fortalt om Poincaré. For at forklare ham hvad "tilfælde" betød, havde han sagt: 'Altså, i den almindelige verden er et tilfælde et tilfælde, den begivenhed, man kalder et tilfælde ifølge Poincarés teori, er, når noget er så komplekst, at det langtfra lige lader sig forklare. [...]' Hvad hans ven havde sagt, kunne han ikke ignorere som blot et nyt fragment af viden, og han tænkte over, hvordan det detaljeret kunne applikeres på ham selv. Når han gjorde det, var det som en mørk, mystisk kraft fra højre skubbede ham til venstre, når han burde gå til højre, og skubbede ham tilbage, når han skulle gå frem, forekom det ham. Alligevel huskede han ikke at have gjort noget mod sin vilje. (Natsume Light 4; SZ II: 8)

Fra de fysiologiske processer til det bevidste liv og individuelle valg, er der et spring, som ikke umiddelbart lader sig forklare. Tsuda er tydeligvis forvirret og forestiller sig, at de andre i togvognen må kunne se det på ham, men da han ser sig omkring, er der umiddelbart ingen, der har registreret hans agitation. Er det sygdommen, der gør, at Tsuda er desorienteret? Er det, fordi han er på et tog, påvirket af andres tilstedeværelse, er det fordi han skuer ud i fremtiden, eller tilbage i fortiden?

22 "If incorporeal materialism is an empiricism it is a radical one, summed up by the formula: the felt reality of relation." (Massumi I6) eller som han skriver i "Introduction to A Shock to Thought": "... we arrive at the magic formula we seek - PLURALISM = MONISM," ATP 20." (Massumi xlii) Ordet kokoro kan betyde begge dele på japansk (desuden titlen på Sōsekis måske mest kendte roman fra I9I2).

24 Sōseki gør brug af en udsigelsesmarkering (kare wa), hvor det ikke er strengt nødvendigt på japansk, sammenligneligt med en understregning af tredjepersonspronomenet han. Se Auestad. 
Hvem styrer hans liv, han selv? Lægen, chefen, konen, den gamle ven, der dukker op? Forvirringen eller intensiteten, der naturligvis også er af mere eksistentiel art, kommer til udtryk kropsligt som ubehag, svimmelhed. Ny viden om kroppen på mikrobiologisk og bakteriologisk niveau ændrer Tsudas situation, men afgør ikke de valg, han føler, han må træffe i det krydsfelt af påvirkninger, han i toget fornemmer som en kropslig tilstand af uro og tvivl. Han kan ligesom ikke rigtig følge med. Eller få hold på sin slingrende krop og blævrende sjæl. Nye transportformer og nye perceptionsmåder ændrer hans selvrelation. Ngai skriver, at en af de mest udbredte måder, hvorpå affekt bliver synlig i den mekaniske reproducerbarheds tidsalder, netop er som innerveret agitation eller animerethed (Ngai, Ugly 3I). Det beskriver den (modernitets)affekt, Tsuda befinder sig i på vej hjem i toget efter lægebesøget. Det er ikke nogen let definerbar enkelt følelse, der kommer indefra, men snarere en form for affekt sammensat af mange små hverdagsindtryk og følelser. Ngai foreslår i Ugly Feelings fra 2005 at se på de mindre følelser i litteraturen, der ikke nødvendigvis er singulære, men ofte tvetydige og sammensatte. Det er ikke skønne eller ophøjede følelser, men beskriver snarere en form for hverdagsaffekt i det moderne liv. Sōseki skriver i I907, at litteraturen netop kan gøre brug af alle mulige følelser: ”At vesterlændinge kun råber op om skønhed og æstetik skal ikke slå os ud”. ${ }_{25}$ Måske derfor begynder han sin sidste roman med en fistelundersøgelse. Når Sōseki definerer følelser som litteraturens omdrejningspunkt, er det således dels for at adskille den litterære fremstillingsform fra den videnskabelige, dels for at åbne for at litteratur kan gøre brug af mange forskellige former for følelser. ${ }^{26}$

Sōsekis romanpersoner er påvirket af forudgående oplevelser såvel som af øjeblikkelige indtryk, mens de bevæger sig rundt i det moderne byrum: hos lægen, i tog - og som vi i det følgende afsnit skal se - i rickshaws, i audiens hos chefens kone, i teateret, og på rekreation på en ryōkan (traditionel japansk kro). Det er eksempler på bestemte sociale rum og relationer, Sōseki skildrer i sin roman. Romanen handler således ikke udelukkende om Tsudas private indre psykologiske eller fysiologiske forandringer. Det bliver desto tydeligere, da føljetonromanen pludselige skifter hovedperson (om end for en kort bemærkning).

\section{Sociabilitet og foljetonromanen}

Med et synsvinkelskift til O-Nobu i kapitel 45 efterlades Tsuda så at sige på operationsbordet, midlertidigt suspenderet fra sit forretningsmandsjob og sin rolle som moderne bekymret romankarakter. Stafetten går kortvarigt videre til hans unge hustru, som læseren nu følger i teateret. O-Nobu har indvilliget $\mathrm{i}$ at ledsage nogle bekendte til et arrangeret ægteskabsmøde (miai)... Flere af Sōsekis romaner

25 "The way Westerners trumpet on only about beauty and aesthetics causes us no end of mischief". (Natsume, Theory 180).

26 "To put it simply, while the scientist is involved in the appeal to reason over disputations of a black and white nature, the literary man seeks to gain control over the emotions - the source of life - to capture and hold it in his hand". (Natsume, Theory 97) 
tematiserer ægteskabsinstitutionen i Japan og særligt skismaet mellem miai kekkon, en japansk form for familiearrangeret ægteskab og ren'ai kekkon, et vestligt inspireret ideal om romantisk kærlighedsægteskab. O-Nobus besøg i teateret fungerer som et lille intermezzo over dette tema. Desuden peger teaterscenen, som vi skal se, på selve den sociale iscenesættelse af følelser. Sōsekis romanpersoner bliver ofte konfronteret med dilemmaer af familiær, økonomisk og romantisk art, der opstår imellem traditionelle (konfucianistiske) familie- og gruppeorienterede værdier og en moderne (vestlig associeret) individualisme. At O-Nobu er ude at more sig, mens Tsuda ligger på operationsbriksen er ofte udlagt som et spørgsmål om, hvem af de to der er mest egoistisk. Det kan dog diskuteres, om Sōsekis anliggende ikke er et andet mere samfundskritisk. Lige så lidt som litteraturen er en sort-hvid videnskab, lige så lidt er den ifølge Sōseki nemlig udtryk for en morallære. ${ }^{27}$ Under alle omstændigheder er O-Nobu på vej til teateret i en rickshaw:

"Eftersom hendes krop hoppede hurtigt op og ned på det tætte, tykke sæde, opstod der også i hendes tanker en slags blød, behagelig vibration/svingning. Det var den rare følelse af at bevæge sig mod sit ønskede bestemmelsessted ved konsekvent/ ubarmhjertigt at skære lige gennem alle de aktive liv, der fór rundt omkring hende.” (Natsume, Light 77; SZ II: I45).

Situationen kan sidestilles med indledningsscenen, hvor Tsuda kører rundt i Tokyo. Der er en klar kontrast mellem O-Nobus bløde, målrettede fornemmelse i rickshawen og Tsudas tidligere fortumlede sporvognstur. At synsvinklen undervejs skifter til O-Nobu, underbygger den distance mellem fortællerstemmen og personerne, som Sōseki vil skabe. Sōseki eksperimenterer udtrykkeligt med en ny form for distanceret variabel fokalisering. Det gør, at vi nu kan følge O-Nobu i teateret og opleve hendes (kanojo no) synsvinkel og særlige kropslige oplevelse af bevægelse, der bliver en metafor for hendes spænding over at skulle i teateret. Som i Balzacs romaner, danner O-Nobus oplevelser i teateret en særlig god ramme for observation af sociale og menneskelige relationer (komedier) udefra: "Det mest besynderlige var tilskuerne. [...] tomt fyldt op af tilfældige impulser, lod de sig bære tankeløst med af øjeblikket.” (Natsume, Light 84; SZ II: I59). Som en kommentar til romanens receptionshistorie karakteriserer Jameson netop Lys og mørkes fremstilling af affekt som en "illusion om tilsynekomst af fortolkelig mening, som et umiddelbart psykologisk indhold har kastet af sig." ${ }^{28}$ Sagt på en anden måde peger Lys og mørke også

27 "There are various positions on literature: some see literature as merely a tool for some high-class form of intellectual entertainment, while others see it as a channel for conveying morality, and so forth. I would like to show these as providing an unnecessarily narrow view of the domain of literature." (Natsume, Theory 59) "[T] he echoes I have retained from the Japanese critical debates on Meian turn essentially on what I consider to be matters of content, namely Tsuda's spiritual state and his putative regeneration, the whole (unfinished) novel coming to seem a psychodrama of archetypical proportions, about which it might be more accurate to say that it is the illusion of appearance of interpretable meaning thrown off by some initial psychological content". (Jameson 300-I) 
på følelsernes sociale ikke-bevidste, en slags følelsernes sociale automatpilot: når tilskuerne tankeløst lader sig føre med af tilfældige impulser. Hvor første kapitel af romanen fokuserede på det fysiologiske som et spørgsmål om det, der er i lys og i mørke i bevidstheden, kaster teaterscenen nu lys på følelsernes ikke-bevidste sociale natur. Jameson kommenterer denne scene: "Det faktum, at den besynderlige intensitet af følelser er associeret med teateret og teaterrummet, distancerer den yderligere og indrammer affekten, fremmedgør den, og foreslår, at de selvsamme følelser, der materialiserer sig så livagtigt mod fortællingens tomhed og upersonlighed, har en dybere, grundlæggende relation til æstetikken og repræsentationen selv.” (Jameson 306) Denne sociale affekt er således et spørgsmål om bestemte sociale former og hverdagsaffekt. Lys og mørke er i den forstand også en iscenesættelse af selve sociabiliteten, de sociale omgangsformer. ${ }^{29}$ Personerne i teateret er selv vævet ind i sociale spil.

Som den norske japanolog Reiko Auestad har påpeget, er et gennemgående mønster af hverdagsærinder et dominerende motiv i flere af Sōsekis romaner. Lys og Mørke forekommer ofte at være en konstant udsættelse af decideret handling. Som tema går det igen på et utal af måder. Tsuda søger fx romanen igennem en afgørelse på en pengemæssig knibe, der begynder med faderens tilbagetrækning af økonomisk understøttelse af det nygifte par. Personerne er ofte på vej. Mødet med en række bipersoner i romanen sker så at sige i en form for mellemrum, der opstår ind imellem disse sociale situationer og ærinder af mere formel eller praktisk karakter. Operationen gør blandt andet, at Tsuda må bede sin chef om fri, men mødet med chefen udskydes hele tiden, fordi han enten ikke er hjemme eller har for travlt. I første omgang ender Tsuda med at tale med chefens hustru, Fru Yoshikawa, hvis indblanding i Tsudas privatliv bliver den egentlige igangsætter af romanens underspillede intrige, idet hun arrangerer, at Tsuda efter operationen kommer til et kursted, hvor hans ungdomsforelskelse Kiyoko også opholder sig for en periode. At rekreere på gæstgiverier (ryōkan) ved varme kilder (onsen) er en integreret del af japansk kultur. Stedets snørklede gange og fælles baderum iblandet intrikate japanske omgangsformer kommer også til at fungere som en stadig udsættelse af deres møde. De stadige ærinder viser personernes indlejring i sociale systemer og moralske kodekser, der samtidig er under opbrud. De bliver derved mønstereksempler på datidens sociale former (og på nye klassemodsætninger) i Japan. Der dukker også udefrakommende, forstyrrende elementer op i romanen. Som Jameson påpeger, synes den Dostojevski-inspirerede Kobayashi fx ikke at passe ind. ${ }^{30}$ Det gør han hverken stilistisk eller samfundsmæssigt, og i romanen er han da også på vej til at emigrere til Korea. Sōseki blander forskellige inspirationskilder

29 Massumis affektteori (der igen låner sine metaforer dels fra mikrofysiologien og dels fra Deleuze) insisterer på en ontogenetisk fremkomst (becoming) af det sociale: "The idea is that there is an ontogenesis, or becoming of culture and the social (bracketing for present purposes the difference between them), of which determinate forms of culture and sociability are the result." (Massumi 9)

30 "[A] Dostoyevskian character of [Kobayashi's] type could not be imagined within the country houses of a Henry James novel” (Jameson 298) 
og stilarter. Ifølge hans teori kan forskellige - ismer som sagt sagtens kombineres, og i Lys og mørke er det med til at skildre et samfund i forandring.

Romanen er ufuldendt (hvilket der er gjort en del ud af i receptionen), men oftest får man alligevel ingen endegyldige svar i Sōsekis romaner, hvor antydninger er hyppigere end konklusioner. Selvom der findes enkelte analepser og prolepser, udfoldes plottet generelt kronologisk som en form for medsyn. Som når Tsuda i sporvognen konstaterer, at det ikke er til at sige, hvornår følelserne ændrer sig. Selve føljetonformens ekstradiegetiske udsættelse er udnyttet som underholdningsmoment: Hvad har personerne tænkt sig, hvad finder forfatteren nu på næste gang? Romanerne afsluttes ofte med en eller anden uklarhed, hvad angår personernes intentioner. I den forstand er det ikke så mærkeligt, at der ofte er digtet videre og givet forskellige bud på motiver og forslag til den videre handling i Sōsekis romaner. De enkelte afsnit/kapitler slutter ofte abrupt, som fx kapitel 5: "Han gik hurtigt ned ad trapperne, der igen gav en knirken fra sig" (Natsume, Light 9; SZ II: I7). ${ }^{\text {I }}$ Man kunne sige, at føljetonformen og hverdagspræget fordrer et forstærket fokus på (hos Sōseki ganske vist ofte minimalt) suspense, og derfor både begynder og ender hvert afsnit in medias res. Har Fru Yoshikawa reelle hensigter ved udgangen af kapitel I2? Er hun ude på at ødelægge Tsuda og O-Nobus ægteskab? Og har ONobu ligefrem fortjent, at ægteskabet går i stykker, som nogen fortolkere mener, når hun handler så egenrådigt? Er Tsuda eller O-Nobu mest egoistisk? (Se fx den engelske oversætter Viglielmos efterord om receptionen af O-Nobu.) Romanen lægger med sin konstante udsættelse og ophobning af hverdagsdetaljer muligvis op til en sådan fortolkende tilgang til personerne og deres bevæggrunde. Ifølge Jameson underbygger føljetonens narrative flow af små afsnit og minutiøse detaljer en minimalistisk hverdagsæstetik, der desuden er forankret i den måde, hvorpå avismediet indgår i en borgerlig produktions- og distributionskultur. ${ }^{22}$ Sōseki udnytter både æstetisk og kommercielt føljetonens særlige format, kunne man også sige. Eller med et udtryk fra Ngai benytter Sōseki sig affektivt af de intersubjektive bevagelsesveje.33 Romanens narrative flow mimer, som jeg har argumenteret for, Sōsekis ide om bevidsthedens flux (som en affektiv strøm). Serialiseringens fortsatte strøm illustrerer derved bevidsthedens bevægelse i et samfund i forandring.

3I På japansk er det en meget lydlig knirken gishi gishi. Onamatopoeia og andre mimetiske ord (såsom phenomimes og psychomimes) indgår som del af et varieret hverdagssprog på japansk. Det er i den forstand en rent lydlig minimal hverdagssuspense (der skulle få datidens læsere til at vende tilbage ugen efter).

32 "[T]hat such an arrangement owned something to journalism and serialization is scarcely an alternative casual explanation, since the form of the newspaper ultimately loops back into the general determinations of bourgeois culture in its own right." (Jameson 300-I).

33 Udtrykket er fra Ngais seneste værk, hvor hun beskriver sådanne intersubjektive bevagelsesveje ift. romanen som en interessant genre. Hun overvejer, hvordan ideen om det interessante i den moderne roman netop sammenfattes af det teoritunge, minimale og selve cirkulationen. 


\section{Antiplot}

Ofte er Sōsekis romaner udtryk for en decideret antiplot-æstetik: Jeg er en kat (I905) er episodisk, Minearbejderen (I908) slutter af med at konkludere, at den aldrig blev til en roman. Måske mest eksplicit karakteriserer Sōseki selv kunstnerromanen Kusamakuras (I9I2) hyperæstetiske higen efter en indfangelse af øjeblikket som et forsøg på at skrive en antiplotroman, eller det han inspireret af Shiki betegner som en haiku-shōsetsu (et andet udtryk for shaseibun-stilens hverdagsæstetik.) Antiplotstrukturen fremhæver Sōseki også som en mere virkelighedstro form for realisme, nærmest som et plot mod plottet. Det smitter af på selve føljetonromanens form, der enten aldrig afrundes, eller netop rundes af, bider sig selv i halen (som den mere groteske, eller satiriske, form for realisme, man ser i de tidlige værker).

Ifølge Sōseki er bevidstheden i flux (med James), eller i bevøgelse kunne man sige for at spille på dette ords dobbeltbetydning på dansk. Sōsekis føljetonromaner begynder in medias res og ender in medias res. De er båret frem af en forestilling om det psykologiske som en bevidsthedsstrøm i og med en krop og en verden. Hans sidste roman viser i detaljen, hvordan nye perceptions- og bevægelsesmåder (som mikroskopet og toget) i det moderne storbyrum influerer forestillingen om kroppen. Med Ngai kan man tale om en kompliceret sammenkrydsning af hverdagsaffekter i hans romaner. Beskrivelsen af følelser i Sōsekis romaner spænder vidt, fra basale kropslige følelser (som sult, kulde, fysisk svimmelhed) i hans første roman til en mere eksistentiel svimmelhed $i$ hans sidste roman. Hverdagsagtige såvel som grimme følelser som mistillid, svig, nag og egoisme er gennemgående i hans senere romaner. (Kedsomhed er derimod ikke portrætteret som en udelukkende dårlig ting, men det er en anden historie fra hans første roman).

Sōsekis iscenesættelse af hverdagsaffekt i Lys og mørke kan i en affektteoretisk optik ses som en kritisk overvejelse over følelsernes sociabilitet og over den videnskabelige følelsesdiskurs, der opstod med den fysiologiske psykologi. Følelser er ikke isolerede punkter. De er del af det affektive kontinuum, som Sōseki beskriver i sin teori. Følelser beskrives kropsligt, men er ikke altid let afgrænselige. Sinds- og kropstilstande synes snarere at overlappe hinanden i føljetonromanens affektive form for bevidsthedsstrøm. Lys og Mørke viser derved, hvordan nye distributionsformer og medier (som avisen og føljetonromanen) påvirker fremstillingen af affekt. Affekten i romanen opstår i bestemte sociale rum. Ifølge Sōsekis teori er både den individuelle og den kollektive bevidsthed i transformation gennem suggestion. Skiftende kollektive fokusser bestemmer med andre ord også, hvad der vækker følelser på et givent tidspunkt og i et givent samfund. 


\section{LITTERATURLISTE}

Auestad, Reiko. Rereading Sōseki. Three Early Twentieth-century Japanese Novels. Wiesbaden:

Harrassowitz, I998.

Gregg, Melissa; Gregory F. Seigworth. The Affect Theory Reader. Durham NC: Duke University Press, 2010.

James, William. Principles of Psychology. vol. I. New York: Dover I950 (I890)

Jameson, Fredric. The Modernist Papers. New York: Verso, 2007.

Karatani, Kōjin. Origins of Modern Japanese Literature. Durham and London: Duke University Press, I993.

Lamarre, Thomas. "Expanded empiricism: Natsume Sōseki with William James”, Oxfordshire: Japan Forum, 20:I. (2008).

Massumi, Brian. Parables for the Virtual: Movement, Affect, Sensation. Durham NC: Duke University

Press 2002.

Moretti, Franco. Modern Epic. London, New York: Verso I996.

Ngai, Sianne. Ugly Feelings. Cambridge: Harvard University Press, 2005.

Ngai, Sianne. Our Aesthetic Categories. Cambridge: Harvard University Press, 2012.

Natsume, Sōseki. Light and Darkness. Transl. Viglielmo. Tokyo: Tuttle, 1972.

Natsume, Sōseki. Theory of Literature, transl. Bourdaghs et al., New York: Columbia University Press, 2009.

Natsume, Sōseki. Sōseki zenshu (SZ). Tokyo: Iwanami shoten, I995.

Ribot, Théodule-Armand. The Psychology of the Emotions. New York and Melbourne: The Walter Scott Publishing Co. I9II.

Tygstrup, Frederik: "Affective Spaces", pp. 195-2II in Panic and Mourning: The Cultural Work of Trauma, red. Daniela Agostinho, Elisa Antz, Cátia Ferreira. Berlin/Boston: Walter de Gruyter, 2012. 